UDC 657.6:336.113.12:006.032(477)

DOI: $10.15673 /$ fie.v13i2.2043

\author{
Stupnytska T. \\ Ph.D., Associate Professor \\ Department of Accounting and Auditing \\ E-mail: t.stupnitska@gmail.com \\ ORCID ID: 0000-0002-2517-2795 \\ Tkachuk $\mathrm{H}$. \\ Doctor of Economics, Associate Professor \\ Department of Accounting and Auditing \\ E-mail: talla2007@ukr.net \\ ORCID ID: 0000-0001-6937-6223
}

\author{
Kuprina $\mathbf{N}$. \\ Doctor of Economics, Associate Professor \\ Department of Accounting and Auditing \\ E-mail:k.natali_@ukr.net \\ ORCID ID: 0000-0003-4645-545X
}

\author{
Baraniuk Kh. \\ Ph.D., Assistant \\ Department of Accounting and Auditing \\ Odesa National Academy of Food Technologies \\ Kanatna str., 112, Odesa, Ukraine, 65039 \\ E-mail: baranyuk.kristina@gmail.com \\ ORCID ID: 0000-0002-3346-0332
}

\title{
AUDIT DEVELOPMENT IN UKRAINE: ASPECTS OF REGULATION OF AUDIT ACTIVITY
}

Auditing in Ukraine is on the path of formation and development, which necessitates the improvement and revision of regulations, which, in turn, leads to an increase in both theoretical and practical aspects of audit and audit activity. Modern conditions of the process of Ukraine's integration into the European space cause the regulatory framework to be adapted to the legislation of the European Union. During the period of operation, the national audit system in Ukraine is constantly improving. The article analyzes the normative documents and publications of scientists to determine aspects of regulatory regulation of audit in Ukraine in connection with its integration and the possibility of adapting existing legislation to the legislation of the European Union. The analysis showed that the audit regulatory system in Ukraine is multilevel, but the main documents governing audit in the country are the Law "On Audit of Financial Statements and Audit activity" and International Standards for Quality Control, Auditing, Review, Other Assurance and Related Services . The levels of normative-legal regulation of audit and the main differences in the structure of normative acts regulating the implementation of audit and audit activities in Ukraine have been considered.

Key words: audit, audit activity, normative-legal regulation of audit activity, International audit standards, internal audit standards.

Statement of the problem and its connection with important scientific and practical tasks. Effective management of enterprises involves making certain decisions that require information on the reliability of the financial statements of counterparty companies, which is provided based on the results of the audit of financial statements.

Audit of financial statements - an audit service to verify the accounting data and indicators of financial statements and / or consolidated financial statements of a legal entity or representative office of a foreign entity or other entity that submits financial statements and consolidated financial statements of the group, in order to express the auditor's independent opinion on its compliance in all material respects with the requirements of national accounting regulations (standards), International Financial Reporting Standards or other requirements [1].

During the period of operation, the national audit system in Ukraine is constantly improving. Modern conditions of the process of Ukraine's integration into the European space cause the adjustment of the regulatory framework to the legislation of the European Union. In this regard, the regulations of auditors and audit firms need to be clarified and reformed in connection with the alignment of national legislation in the field of audit activity in line with European Union law (with the provisions of Directive 2006/43 / EC and Regulation (EU ) 537/2014). One of the directions of such reform was the introduction of the Law of Ukraine "On Audit of Financial Statements and Audit Activity". The path of Ukraine's accession to the European Union makes appropriate requirements for accounting and reporting, harmonization of national accounting and audit on a European scale, but there are a number of problems that require the attention of both scholars and practitioners.

The analysis of the latest publications on the problem. The issues of normative and legislative aspects of the audit were considered in the works of such scientists as Bondar V., Hevlych L., Horyayeva O., Hutsalenko O., Drozdova A., Kylivnyk H., Ostap'yuk N., Podolyanchuk O., Red'ko O., Fabiyans'ka V. and others. But scholars and practitioners do not have a single approach 
to defining the audit regulatory system in Ukraine, and that requires further research on this issue.

Forming of the aims of the research. The purpose of the article is to analyze the normative documents and publications of scientists to determine aspects of regulation of audit in Ukraine in connection with its integration and the possibility of adapting existing legislation to the legislation of the European Union.

Giving an account of the main results and their substantiation. In the world practice, there are two concepts of regulation of audit activity. In most European countries (France, Germany, Italy, Spain and Austria), the peculiarity of the audit is its focus on government agencies and banks, which are the main users of reporting and audit information, so the audit is strictly regulated and controlled by the state (government regulation of audit activities).

In the countries of the Anglo-American system (USA and Great Britain and others, developing countries under their influence) the peculiarity of the audit organization is its focus on non-state users - shareholders, investors, insurance companies, investment funds, so the audit is regulated by professional public audit organizations and is minimally controlled by the state. Regulation of audit in Ukraine is carried out in accordance with the Anglo-American approach - the state only sets the list of requirements for the audit, and the methodology is determined by such professional public audit organizations as the Audit Chamber of Ukraine, the Union of Auditors of Ukraine and their branches by approving standards. norms, regulations, instructions, explanations [5].

In the economic literature there is no single approach to defining the system of regulation of audit activity in Ukraine. Some scholars identify certain levels of audit regulation.

Thus, Bondar V. distinguishes soft, rigid and mixed models of organization and regulation of auditing [3]. The soft model is used in the USA, Great Britain, the Republic of Bulgaria, the hard model in France, Germany, Israel, Poland, the Russian Federation, the Republic of Belarus, the mixed model in Ukraine, the Czech Re public, the Republic of Lithuania, and the Republic of Moldova. But the distribution is conditional, because the state in any country supervises audit activities to some degree, so most models are mixed.

Hevlych L. and Kylivnyk H. believe that the system of regulation of audit in Ukraine is two-tier (International standards of quality control, audit, inspection, other assurance and related services and internal standards) and is based on joint state-professional regulation [5].

According to Podolyanchuk O., it is necessary to distinguish three levels [7]: state (Constitution, Commercial Code, Civil Code), professional (Law of Ukraine "On Audit of Financial Reporting and Auditing" and other Laws of the Verkhovna Rada) and internal regulation (International Audit Standards). , acts of the Audit Chamber of Ukraine (normative, local, interpretations), internal audit standards.

Also in the opinion of the author to the regulatory support of the audit activity we should include level IV - special - Other regulations of ministries and departments, P (S) BU, Guidelines, recommendations and instructions, etc. Some scholars distinguish four main levels: first-level documents define the place, role and tasks of auditing in the financial and economic system (Law of Ukraine "On Audit otFinancial Statements and Audit activity"), second-level documents define general issues of audit regulation, which are mandatory for all audit entities (various laws and regulations), the third level is represented by documents establishing rules that are also mandatory for all actors in the audit services market (external audit standards), the fourth level includes documents, detailing and defining uniform requirements for the conduct and design of internal audit of firms (internal standards of audit firms, approved by them to ensure the effectiveness of auditors word and its adequacy to the requirements of International Standards on Audit) [4].

In our opinion, the most appropriate among the existing systems of regulation of audit activity is a multilevel system considered by Fabiyans'ka V. and Hutsalenko O., which includes five levels of regulation of independent audit in Ukraine [9].

Table 1

Levels of legal regulation of the independent audit in Ukraine [9]

\begin{tabular}{|l|l|l|}
\hline $\begin{array}{c}\text { Level } \\
\text { of regulation }\end{array}$ & \multicolumn{1}{|c|}{$\begin{array}{c}\text { Document / } \\
\text { group of documents }\end{array}$} & \multicolumn{1}{c|}{ Characteristics } \\
\hline Level I & Economic Code of Ukraine & $\begin{array}{l}\text { Since audit activity is a type of business activity, respectively, in } \\
\text { Art. 362 of the Commercial Code of Ukraine its stipulated that } \\
\text { audit activity is an independent professional activity of auditors } \\
\text { and audit entities registered in the Register of auditors and audit } \\
\text { entities for provision of audit services. }\end{array}$ \\
\hline Level II & $\begin{array}{l}\text { Law of Ukraine "On Audit } \\
\text { of Financial Statements and } \\
\text { Audit Activities" }\end{array}$ & $\begin{array}{l}\text { Defines the legal basis for the audit of financial statements, audit } \\
\text { activity in Ukraine, regulates the relations arising from its imple- } \\
\text { mentation, and brings the rules of national legislation in the field } \\
\text { of audit activity in accordance with European Union law }\end{array}$ \\
\hline Level III & $\begin{array}{l}\text { International standards for } \\
\text { quality control, audit, in- } \\
\text { spection, other assurance } \\
\text { and related services }\end{array}$ & $\begin{array}{l}\text { Code of Ethics for Professional Accountants [10] Auditing stand- } \\
\text { ards form uniform basic regulatory requirements for the quality } \\
\text { and reliability of audit, which ensure compliance with a certain } \\
\text { level of assurance of audit results. As the economic situation in } \\
\text { the country changes, the standards may be revised periodically. }\end{array}$ \\
\hline
\end{tabular}


Continue of table 1

\begin{tabular}{|l|l|l|}
\hline $\begin{array}{c}\text { Level } \\
\text { of regulation }\end{array}$ & \multicolumn{1}{c|}{$\begin{array}{c}\text { Document / } \\
\text { group of documents }\end{array}$} & \multicolumn{1}{c|}{ Characteristics } \\
\hline \multirow{5}{*}{ Level IV } & $\begin{array}{l}\text { On the basis of audit standards, training programs for the training } \\
\text { of auditors and uniform requirements for conducting qualifying } \\
\text { examinations for the certification of auditors are formed. Audit } \\
\text { standards determine the general approach to the audit, the scope } \\
\text { of the audit, the types of auditors' reports, issues of methodology, } \\
\text { the basic principles of professional ethics, which must be fol- } \\
\text { lowed by all audit entities }\end{array}$ \\
\hline Level V & $\begin{array}{l}\text { Audit Chamber of Ukraine, } \\
\text { other legislative acts regulat- } \\
\text { ing the audit }\end{array}$ & $\begin{array}{l}\text { This level is formed by documents on professional regulation of } \\
\text { auditing activities, which are entrusted to the Public Oversight } \\
\text { Body, the Audit Chamber of Ukraine. The purpose of their activ- } \\
\text { ities is to ensure the high quality of auditing activities and protect } \\
\text { the interests of auditees. Such documents also determine the au- } \\
\text { ditor's responsibility for the inadequate quality of audit services }\end{array}$ \\
\hline In-house audit standards & $\begin{array}{l}\text { Internal Audit Standards (IAS) are a set of principles, methods, } \\
\text { techniques and methods used by an audit firm in providing audit } \\
\text { services, preparation of documentation, based on the established } \\
\text { rules and features of the audit firm }\end{array}$ \\
\hline
\end{tabular}

Thus, in table 1 shows the main regulations governing audit activity in Ukraine, the most important of which are the Law "On Audit of Financial Statements and Audit Activity" and International Standards for Quality Control, Audit, Review, Other Assurance and Related Services.

The Law of Ukraine "On Audit of Financial Statements and Audit Activity" defines: the concept of audit; subjects of audit activity, their rights, duties, special requirements and responsibilities; the procedure for providing audit services; management of audit activities; other issues. Also, the Law of Ukraine "On Audit of Financial Statements and Audit Activities" established a Public Oversight Body (consisting of the Audit Oversight Board and the Quality Assurance Inspectorate), which will primarily monitor the quality of audit services provided to the enterprises of public. Interest and determines the features of the mandatory audit and audit of enterpris-

\section{es of public interest.}

The Law of Ukraine "On Audit of Financial Statements and Audit Activities" was enacted on January 1, 2018, until now auditing activities were regulated by the Law "On Audit Activities" of April 22, 1993 № 3125$\mathrm{CP}$ (as amended) ). For a more detailed analysis of the Law of Ukraine "On Audit of Financial Statements and Audit Activity", in our opinion, it is first necessary to determine its differences from the previous legislative act in the field of audit and audit, namely the Law of Ukraine "On Audit Activity". The main difference between the structure of the New Law and the previous one is its significant expansion, which consists of Chapter IX with 52 articles and final provisions, while the previous Law consisted of Chapter VI with 22 articles and final provisions.

In our opinion, it is necessary to consider the main differences in the structure of these regulations (table 2).

Table 2

Analysis of the structure of the current Law of Ukraine "On Audit of Financial Statements and Audit Activity" and the Law of Ukraine "On Audit" on the regulation of audit and audit activity*

\begin{tabular}{|c|c|c|c|c|}
\hline \multirow{2}{*}{$\begin{array}{l}\text { № } \\
\text { sec- } \\
\text { tion }\end{array}$} & \multicolumn{2}{|l|}{ Law of Ukraine "On auditing" } & \multicolumn{2}{|c|}{$\begin{array}{l}\text { Law of Ukraine "On the audit of financial statements and } \\
\text { auditing activities" }\end{array}$} \\
\hline & Section name & $\begin{array}{c}\text { Article } \\
\text { numbers }\end{array}$ & Section name & $\begin{array}{c}\text { Article } \\
\text { numbers }\end{array}$ \\
\hline $\mathrm{I}$ & Terms & $1-9$ & Terms & $1-12$ \\
\hline II & $\begin{array}{l}\text { Certification of auditors and register } \\
\text { of audit firms and auditors }\end{array}$ & $10-11$ & Professional standards and audit report & $13-14$ \\
\hline III & Audit Chamber of Ukraine & $12-15$ & Public oversight of auditing activities & $15-18$ \\
\hline IV & $\begin{array}{l}\text { The procedure for conducting audits } \\
\text { and providing other audit services }\end{array}$ & $16-17$ & Certification of auditors & 19 \\
\hline V & $\begin{array}{l}\text { Rights and responsibilities of auditors } \\
\text { and audit firms }\end{array}$ & $18-20$ & Registration of auditors and audit entities & $20-22$ \\
\hline VI & $\begin{array}{l}\text { Responsibility of auditors and audit } \\
\text { firms }\end{array}$ & $21-22$ & $\begin{array}{l}\text { Features of the mandatory audit and audit of } \\
\text { enterprises of public interest }\end{array}$ & $23-39$ \\
\hline VII & Final provisions & 6 points & Ensuring the quality of audit services & $40-41$ \\
\hline VIII & - & - & $\begin{array}{l}\text { Professional responsibility of auditors and audit } \\
\text { actors }\end{array}$ & $42-45$ \\
\hline IX & - & - & Professional self-government of auditors & $46-52$ \\
\hline $\mathrm{X}$ & - & - & Final and transitional provisions & 12 points \\
\hline
\end{tabular}

*Compiled by the authors based on sources $[1,2]$ 
As can be seen from table 2 the structure of the current law is significantly different from the previous one, new sections have appeared, and the articles of the law have significantly expanded the provisions and explanations to it, also expanding the scope of its influence.

Also, the Law of Ukraine "On Audit of Financial Statements and Audit Activities" established a Public Oversight Body (consisting of the Audit Oversight Board and the Quality Assurance Inspectorate), which will primarily monitor the quality of audit services provided to public enterprises interest and determine the features of the mandatory audit and audit of enterprises of public interest.

According to the legislation [1], the Public Oversight Audit Authority is a legal entity under public law, which is not for profit and is obliged to keep accounts, submit and publish financial statements prepared in accordance with International Financial Reporting Standards, and its annual financial statements are subject to mandatory audit by an independent audit entity, the selection procedure of which is determined by the Cabinet of Ministers of Ukraine. Rights, responsibilities, financing, liquidation, etc. of the Public Oversight Body for Audit Activities, as well as the procedure for formation and functioning of the Supervisory Board, formation and functioning of the Inspectorate and disclosure of information about its activities are provided by Articles $15-18$ of Section III audit of financial statements and audit activities "[1].

Thus, according to Art. 15 of Section III of the Law of Ukraine "On Audit of Financial Statements and Audit Activities" - "The body of public oversight of audit activities provides supervision and is responsible for overseeing: - registration of auditors and audit entities; implementation of International Standards on Audit; control over the certification of auditors and continuous training of auditors who carry out mandatory audit of financial statements; - disciplinary proceedings against auditors and audit entities that carry out mandatory audit of financial statements; - application of penalties. ... considers cases of administrative offenses (including at the request of users of financial statements) related to violations of the law in terms of failure to provide information to the Public Oversight Audit Authority in cases provided by this Law, and failure to disclose financial statements together with the audit report "[1]. At the same time, the Law stipulates that part of the powers may be delegated to the Audit Chamber of Ukraine in the absence of the possibility of conflicts of interest, in this case, the Public Oversight Body supervises the exercise of these powers, and in case of systematic non-fulfillment, conflict of interest in the implementation and violation of the Law of Ukraine "On Audit of Financial Statements and Audit Activity" the body of public oversight of auditing should initiate an extraordinary congress of auditors to terminate the powers of members of the UBA Council [1].

The following powers may be delegated to the Audit Chamber of Ukraine by the Public Oversight Body for Audit Activities: - "registration of auditors and audit entities; - control over the continuous training of auditors who carry out the mandatory audit of financial statements of enterprises of public interest; - quality control of audit services of audit entities that carry out mandatory audit of financial statements, except for the audit of financial statements of enterprises of public interest; - carrying out disciplinary proceedings against audit entities that audit the financial statements of enterprises of public interest "[1].

In carrying out audit activities, in addition to the Law of Ukraine "On Audit of Financial Statements and Audit Activities", auditors also use the relevant audit standards: international; national; intra-firm. The general approach to the audit, the scope of the audit, the types of auditor's reports, the methodology and the basic principles to be followed by the auditors, determine the international audit standards [10].

International Standards on Audit (ISAs) are a set of professional standards that establish rules for the provision of audit services and address ethics and quality control issues as defined by International Standards on Quality Control, Audit, Review, Other Assurance and Related Services adopted by the International Audit Council audit and assurance standards, as well as the International Code of Ethics, adopted by the Council on International Standards of Ethics for Accountants and promulgated by the International Federation of Accountants [1].

International auditing standards are classified into 10 groups (table 3 ).

Classification of International Standards on Audit*

\begin{tabular}{|l|l|}
\hline \multicolumn{1}{|c|}{ ISA Groups } & \multicolumn{1}{c|}{ Characteristics } \\
\hline $\begin{array}{l}\text { Group 1 } \\
\text { "Introductory remarks" }\end{array}$ & $\begin{array}{l}\text { Standards, that define the legal status of ISAs contain a list of terms, describe the } \\
\text { structure of ISAs and provide a classification of related services (ISA 100-120). }\end{array}$ \\
\hline $\begin{array}{l}\text { Group 2 } \\
\text { "Obligations" }\end{array}$ & $\begin{array}{l}\text { Standards, that define the objectives and basic principles of audit, the responsibilities } \\
\text { of audit and auditors, address issues related to quality control of auditors, the form and } \\
\text { content of working papers, define the concepts of "fraud" and "error" (ISA 200-260). }\end{array}$ \\
\hline $\begin{array}{l}\text { Group 3 } \\
\text { "Planning" }\end{array}$ & $\begin{array}{l}\text { Standards, describing the process of planning audits, the auditor's understanding of the } \\
\text { client's business, gives an interpretation of the concept of materiality in the audit (ISA } \\
\text { 300-320). }\end{array}$ \\
\hline $\begin{array}{l}\text { Group 4 } \\
\text { "Costs (system) of in- } \\
\text { ternal control" }\end{array}$ & $\begin{array}{l}\text { Standards, describing the processes of risk assessment and internal control systems of } \\
\text { the client, including when the client uses computer information systems, as well as if } \\
\text { the client's accounting is conducted by service organizations (accounting and audit } \\
\text { firms) (ISA 400-402). }\end{array}$ \\
\hline
\end{tabular}


Continue of table 3

\begin{tabular}{|l|l|}
\hline \multicolumn{1}{|c|}{ ISA Groups } & \multicolumn{1}{|c|}{ Characteristics } \\
\hline $\begin{array}{l}\text { Group 5 } \\
\text { "Audit evidence" }\end{array}$ & $\begin{array}{l}\text { Standards, that define the process of collecting audit evidence in different situations, } \\
\text { reveal the content and nature of analytical procedures, spot checks (ISA 500-580). }\end{array}$ \\
\hline $\begin{array}{l}\text { Group 6 } \\
\text { "Using the work of third } \\
\text { parties" }\end{array}$ & $\begin{array}{l}\text { Standards describing the use of other independent auditors, the client's internal audi- } \\
\text { tors, experts and specialists in various fields during audits (ISA 600-620). }\end{array}$ \\
\hline $\begin{array}{l}\text { Group 7 } \\
\text { "Audit conclusions and } \\
\text { reports" }\end{array}$ & $\begin{array}{l}\text { Standards, that provide recommendations on the form and content of audit conclu- } \\
\text { sions, preparation of auditors' reports, the procedure for including additional infor- } \\
\text { mation in these reports. (ISA 700-720). }\end{array}$ \\
\hline $\begin{array}{l}\text { Group 8 } \\
\text { "Specialized audit areas" }\end{array}$ & $\begin{array}{l}\text { Standards, that define an auditor's action during formation of the report on special } \\
\text { audit task, as well as in the study of projected audit information (ISA 800-810). }\end{array}$ \\
\hline $\begin{array}{l}\text { Group 9 } \\
\text { "Related services" }\end{array}$ & $\begin{array}{l}\text { Standards, that guide auditors in the provision of related services: general audits of } \\
\text { financial statements, compliance with agreed procedures, compilation (preparation) } \\
\text { of financial statements (ISA 910-930). }\end{array}$ \\
\hline $\begin{array}{l}\text { Group 10 } \\
\text { "Regulations on Interna- } \\
\text { tional Audit Practice" }\end{array}$ & $\begin{array}{l}\text { standards, which disclose the features of the audit of international banks, as well as } \\
\text { the features of the audit in the case of customers using computer information sys- } \\
\text { tems. This group also addresses various issues of conducting audits of checks: com- } \\
\text { munication with customer management, audit of small businesses, etc. (ISA 1000- } \\
\text { 1010). }\end{array}$ \\
\hline
\end{tabular}

* Compiled by the authors based on sources [10]

In the system of regulation of audit activity an important role belongs to internal standards - a set of principles, methods, techniques and methods used by the audit firm to provide audit services, compilation and presentation of their results, based on established rules and features of the audit firm [7]. It is especially important to apply internal standards in the activities of audit firms during the inspection of enterprises in certain industries that have certain features of activity, including food industry enterprises, such as meat and meat products enterprises; processing and canning of fish, crustaceans and mollusks; production of oil and animal fats; production of products of the flour and cereals industry, starches and starch products; grape wines, etc. and various organizational forms (micro and small business enterprises, medium business enterprises, large business enterprises, associations of enterprises, etc.).

Conclusions and prospects of the further investigations. The results of the fulfilled study allow us to draw the following conclusions:

- audit activity in Ukraine is on the path of formation and development, which causes the improvement and revision of regulations, which, in turn, leads to an increase in both theoretical and practical aspects of audit and audit activity;

- the study showed that the audit regulatory system in Ukraine is multilevel and based on the Commercial Code of Ukraine, the Law of Ukraine "On Audit of Financial Statements and Audit Activity", international standards of quality control, audit, review, other assurance and related services, provisions, internal standards, but the main documents governing the audit activities in the country are the Law "On Audit Financial Statements and Audit Activity " and International Standards for
Quality Control, Audit, Review, Other Assurance and Related Services.

- analysis of the structure of the current Law of Ukraine "On Audit of Financial Statements and Audit Activity" and the Law of Ukraine "On Audit Activity " on the regulation of audit and audit activity showed that the current law is more extensive and detailed, has additional sections and that created the Public Authority supervision, which will control the quality of audit services and determine the features of the statutory audit and audit of enterprises of public interest.

- the study showed that International Standards are the basic provisions, the basis for conducting and regulating audit activities in Ukraine, but to ensure high quality audits in modern conditions of audit firms, streamlining and facilitating of audit work, comparability of quality of individual audit organizations , the connection of certain elements of the audit process, the introduction of new research into audit practice, as well as eliminating the need for control by the state, etc., which leads to professional growth of the firm, increase of its rating and competitiveness in the audit services market, we need is the application of internal standards which requires further research.

- The study showed that recently the country has undergone important changes in the field of audit, aimed at improving the quality of audit and harmonization of national accounting and auditing in Europe, but which require further improvement and transformation of domestic legislation in connection with Ukraine's integration to the countries of the European Union and conducting future research on the regulation of audit activities in Ukraine. 


\section{References}

1. Pro audyt finansovoi zvitnosti ta audytorsku diialnist: Zakon Ukrainy №2258-VIII vid 21.12.2017 r.: za stanom na 01.07.2020 r. (2020). Verkhovna Rada Ukrainy. https://zakon.rada.gov.ua/laws/show/2258-19\#Text

2. Pro audytorsku diialnist: Zakon Ukrainy № 3125-KhP vid 22 kvitnia 1993 r.: za stanom na 01.10.2018. (2018). Verkhovna Rada Ukrainy. https://zakon.rada.gov.ua/laws/show/3125-12\#Text

3. Bondar, V. P. (2008). Systema orhanizatsii ta rehuliuvannia audytorskoi diial-nosti krain svitu. Mizhnarodnyi zbirnyk naukovykh prats, (2(11), 5-20.

4. Burova, T. Suchasna model rehuliuvannia ta nahliadu audytorskoi diialnosti v ukraini ta za kordonom. http://mdu.edu.ua/wp-content/uploads/Econom-visnyk-11-33.pdf

5. Hevlych, L. L., \& Kylivnyk, H. Normatyvne rehuliuvannia vitchyznia-noho audytu. https://goo.su/6H2k

6. Panteleiev, V. P. (2020). Konsolidatsiia informatsii z rehuliuvannia audytu, orhanizatsii i metodyky audytu v krainakh YeS. Ekonomika: realii chasu, (1(47), 91-113. doi: 10.15276/ETR.01.2020.11

7. Podolianchuk, O. A. (2015). Derzhavne rehuliuvannia audytorskoi diialnosti ta nezalezhnoho audytu v Ukraini. In L. V. Hutsalenko (Ed.), Istoryko-teoretychni aspekty rozvytku obliku, kontroliu i analizu v Ukraini ta sviti (pp. 46-64).

8. Redko, O. Yu. (2018). Yak zhyty dali vitchyznianym audytoram (novely zakono-davchoho rehuliuvannia audytu v Ukraini). Naukovyi visnyk Natsionalnoi aka-demii statystyky, obliku ta audytu, (1-2), 77-95. doi: 10.31767/nasoa.1-2.2018.08

9. Fabiianska, V. Yu., \& Hutsalenko, O. O. (2020). Normatyvno-pravove zabezpechen-nianezalezhnoho audytu v Ukraini. The scientific heritage, (45). R.5, 35-45.
10. Mizhnarodni
standarty
audytu.
Ukrainskyi
portal
audytu.

http://proaudit.com.ua/audit/mijnarodni_standarti_auditu

Received 25 April 2021

Approved 8 May 2021

Available in Internet 21.07.2021

Ступницька Т.M.

кандидат економічних наук, доцент кафедра обліку та аудиту

E-mail: t.stupnitska@gmail.com

ORCID ID: 0000-0002-2517-2795

Ткачук Г.О.

доктор економічних наук, доцент кафедра обліку та аудиту

E-mail: talla2007@ukr.net

ORCID ID: 0000-0001-6937-6223

\section{Купріна Н.M.}

доктор економічних наук, доцент кафедра обліку та аудиту

E-mail:k.natali_@ukr.net

ORCID ID: 0000-0003-4645-545X

Баранюк X.O.

доктор фрілософії, старший викладач кафедра обліку та аудиту

Одеська національна академія харчових технологій вул. Канатна, 112, м. Одеса, Україна, 65039

E-mail: baranyuk.kristina@gmail.com

ORCID ID: 0000-0002-3346-0332

\section{РОЗВИТОК АУДИТУ В УКРАЇНІ: АСПЕКТИ РЕГУЛЮВАННЯ АУДИТОРСЬКОї ДІЯЛЬНОСТІ}

Аудиторська діяльність в Україні перебуває на шляху становлення та розвитку, пов'язаних з інтеграцією України до європейського простору, що викликає необхідність вдосконалення та перегляду нормативно-правових актів та їх пристосування до законодавства країн Європейського Союзу, це, в свою чергу, призводить до підвищення рівня як теоретичних, так й практичних аспектів аудиту та аудиторської діяльності. За період функціонування національна система аудиту в Україні постійно удосконалюється. В статті проведено аналіз нормативних документів та публікацій вчених щодо визначення аспектів нормативного регулювання аудиторської діяльності в Україні у зв'язку з її інтеграцією та можливістю адаптації чинного законодавства до норм законодавства країн Європейского Союзу. Аналіз показав, що система нормативного регулювання аудиту в Україні $\epsilon$ багаторівневою, але основними документами, що регулюють аудиторську діяльність в країні є Закон «Про аудит фрінансової звітності та аудиторську діяльність» та Міжнародні стандарти контролю якості, аудиту, огляду, іншого надання впевненості та супутніх послуг. В статті розглянуті рівні нормативно-правового регулювання аудиту та основні відмінності у структурі нормативних актів, що регулюють здійснення аудита та аудиторської діяльності в Україні. Визначено, що для забезпечення високої якості проведення аудиторсь- 
ких перевірок в сучасних умовах діяльності аудиторських фрірм, раціоналізації та полегшення аудиторської роботи, порівнянності якості роботи окремих аудиторських організацій, зв'язку окремих елементів аудиторського процесу, впровадження в аудиторську практику нових наукових досліджень, а також усунення необхідності контролю з боку держави тощо, що призводить до професійного росту фірми, підвищення її рейтингу та конкурентноздатності на ринку аудиторських послуг є застосування внутрішньофрірмових стандартів.

Ключові слова: аудит, аудиторська діяльність, нормативне-правове регулювання аудиторської діяльності, Міжнародні стандарти аудиту, внутрішньофірмові стандарти аудиту.

\section{Література}

1. Про аудит фінансової звітності та аудиторську діяльність: Закон України №2258-VIII від 21.12.2017 р.: за станом на 01.07.2020 p. / Верховна Рада України URL: https://zakon.rada.gov.ua/laws/show/2258-19\#Text (дата звернення: 15.04.2021 р.)

2. Про аудиторську діяльність: Закон України № 3125-ХП від 22 квітня 1993 р.: за станом на 01.10.2018 / Верховна Рада України URL: https://zakon.rada.gov.ua/laws/show/3125-12\#Tехt (дата звернення: 15.04.2021 p.)

3. Бондар В.П Система організації та регулювання аудиторської діяльності країн світу // Міжнародний збірник наукових праць. Випуск 2(11). 2008. С. 5-20.

4. Бурова Т. Сучасна модель регулювання та нагляду аудиторської діяльності в україні та за кордоном URL: http://mdu.edu.ua/wp-content/uploads/Econom-visnyk-11-33.pdf (дата звернення: 15.04.2021р.)

5. Гевлич Л.Л. та Килівник Г. Нормативне регулювання вітчизняного аудиту. URL: https://goo.su/6H2k (дата звернення: 15.04.2021 р.).

6. Пантелеєв В.П. Консолідація інформації з регулювання аудиту, організації і методики аудиту в країнах СС // Економіка: реалії часу. 2020. № 1(47). C.91-113. doi: 10.15276/ETR.01.2020.11

7. Подолянчук О.А. Державне регулювання аудиторської діяльності та незалежного аудиту в Україні. Історико-теоретичні аспекти розвитку обліку, контролю і аналізу в Україні та світі: колективна монографія. За ред. Л.В. Гуцаленко. Вінниця: 2015. 266 с. (С. 46-64).

8. Редько О.Ю. Як жити далі вітчизняним аудиторам (новели законодавчого регулювання аудиту в Україні). Науковий вісник Національної академії статистики, обліку та аудиту. 2018. № 1-2. С. 77-95. doi: 10.31767/nasoa.1-2.2018.08

9. Фабіянська В. Ю., Гуцаленко О.О. Нормативно-правове забезпеченнянезалежного аудиту в Україні // The scientific heritage. 2020. № 45. P.5. C. 35-45

10. Український портал аудиту: [Веб-сайт] / Міжнародні стандарти аудиту. URL: http://proaudit.com.ua/audit/mijnarodni_standarti_auditu (дата звернення: 15.04.2021р.)

Стаття надійшла 25.04.2021

Стаття прийнята до друку 8.05.2021

Доступно в мережі Internet 21.07.2021

Цитування згідно ДСТУ 8302:2015

Stupnytska T., Kuprina N., Tkachuk H., Baraniuk Kh. Audit development in Ukraine: aspects of regulation of audit activity // Food Industry Economics. 2021. Vol.13, Issue 2. P. 80-86. doi: 10.15673/fie.v13i2.2043

Cite as APA style citation

Stupnytska, T., Kuprina, N., Tkachuk, H., \& Baraniuk, Kh. (2021). Audit development in Ukraine: aspects of regulation of audit activity. Food Industry Economics, 13(2), 80-86. doi: 10.15673/fie.v13i2.2043 